\title{
Identifikasi Faktor-Faktor yang Mempengaruhi Kelayakan Donor Darah di STIKes Santa Elisabeth Medan Tahun 2019
}

\author{
Paska Ramawati Situmorang ${ }^{1}$, Widya Yanti Sihotang ${ }^{2}$, Lilis Novitarum ${ }^{3}$ \\ ${ }^{1,2}$ Teknologi Laboratorium Medik, STIKes Santa Elisabeth Medan \\ ${ }^{3}$ Ilmu Keperawatan, STIKes Santa Elisabeth Medan
}

\begin{tabular}{l}
\hline Article Info \\
\hline Article history: \\
Received, Jun $04^{\text {th }}, 2020$ \\
Revised, Aug $21^{\text {th }}, 2020$ \\
Accepted, Sep $03^{\text {rd }}, 2020$ \\
\end{tabular}

\section{Keyword:}

Blood donation

Factors influencing donor

eligibility

\begin{abstract}
Donation is the activity of delivering blood or blood-based products from one person to another person's circulatory system. The mortality rate due to the unavailability of blood reserves for transfusion in the developing countries is relatively high. Indonesia has a level of contributors of 6-10 people per 1000 population which is much smaller compared to several small countries in Asia. The purpose of this study is to identify the factors that affect the eligibility status of blood donors from STIKes Saint Elisabeth Medan 2019 and analyzed based on the results of the examination by the Naive Bayes Classifier method. Data were statistically evaluated using Chi square test. Based on the results, the general characteristics of prospective blood donors are students, women, the age group of 16-35 years, body weight $>50 \mathrm{~kg}$ and normal Hemoglobin status. We found there were only $38.85 \%$ of respondents who had the status "Can Donor" with the most common characteristics of blood type 0 , women, ages 16-35 years, body weight $>50 \mathrm{~kg}$ and all respondents had normal Hemoglobin levels. Based on statistical tests conducted, there is a closed relationship between body weight with normal Hemoglobin conditions and normal Hemoglobin conditions with donor eligibility status, while gender does not has a significant relationship to Hemoglobin condition or blood donor eligibility status. In conclusion, this study indicates that body weight and normal Hemoglobin status are aspects that should be considered by potential donors. This study recommends that improving health status, especially Hemoglobin status and normal body weight become a promising aspect in increasing the success of blood donors.
\end{abstract}

Copyright $@$ Jurnal Analis Medika Biosains (JAMBS) All rights reserved.

\section{ABSTRAK}

Donor darah adalah kegiatan menyalurkan darah atau produk berbasis darah dari satu orang ke sistem peredaran orang lainnya. Angka kematian akibat tidak tersedianya cadangan darah untuk transfusi pada negara berkembang relatif tinggi. Indonesia memiliki tingkat penyumbang sebanyak 6-10 orang per 1000 penduduk yang jauh lebih kecil dibandingkan dengan beberapa negara kecil di Asia. Tujuan dari penelitian ini adalah untuk mengidentifikasi faktor-faktor yang mempengaruhi status kelayakan donor darah dari dosen/mahasiswa STIKes Santa Elisabeth Medan tahun 2019 dan dianalisis berdasarkan hasil pemeriksaan dengan metode Naive Bayes Classifier. Data dievaluasi secara statistik menggunakan uji Chi square. Berdasarkan hasil penelitian yang dilakukan, karakteristik umum calon pendonor darah adalah mahasiswa/i, perempuan, kelompok usia 16-35 tahun, berat badan $>50 \mathrm{~kg}$ dan status hemoglobin normal. Kami menemukan hanya ada $38.85 \%$ responden yang memiliki status "Boleh Donor" dengan karakteristik umum golongan darah 0 terbanyak, perempuan, usia 16-35 tahun, berat badan $>50 \mathrm{~kg}$ dan semua responden memiliki kadar hemoglobin normal. Berdasarkan uji statistik yang dilakukan, terdapat hubungan erat antara berat badan dengan kondisi hemoglobin normal dan kondisi hemoglobin normal dengan status kelayakan donor, sedangkan jenis kelamin tidak memiliki hubungan yang signifikan terhadap kondisi hemoglobin 


\section{Jurnal Analis Medika Biosains (JAMBS)}

Vol.7, No.2, September 2020, pp. 122 - 129

ISSN: 2656-2456 (Online)

ISSN: 2356-4075 (Print)

maupun status kelayakan donor darah. Sebagai kesimpulan, penelitian ini mengindikasikan bahwa berat badan dan status hemoglobin darah menjadi aspek yang harus diperhatikan calon pendonor darah. Penelitian ini merekomendasikan bahwa perbaikan status kesehatan khususnya hemoglobin darah dan berat badan calon pendonor menjadi aspek yang menjanjikan dalam peningkatan keberhasilan donor darah.

Kata Kunci : Donor Darah, Faktor Mempengaruhi Kelayakan Donor

\section{Pendahuluan}

Donor darah merupakan salah satu kegiatan penting dalam bidang kesehatan yaitu pengambilan darah dari seseorang secara sukarela untuk disimpan di bank darah. Tujuan donor darah adalah untuk penggunaan darah bagi keperluan pengobatan dan pemulihan kesehatan yang mencakup masalah pengadaan, pengolahan, dan penyampaian darah kepada pasien (Munandar, 2008; Beliën \& Forcé, 2012). Sedangkan transfusi darah menjadi salah satu upaya kesehatan sebagai proses penyaluran darah baik berupa darah lengkap atau komponen darah dari satu orang ke sistem peredaran darah orang lain untuk pemulihan kesehatannya (Departemen Kesehatan RI, 2001). Transfusi darah berhubungan dengan kondisi medis seperti kehilangan darah dalam jumlah besar yang disebabkan oleh trauma, operasi, syok, dan tidak berfungsinya organ pembentuk sel darah merah (Sugesty, 2009; Lestariyani \& Herawati, 2017).

Ketersediaan darah di bank darah sangat penting bagi mereka yang memerlukan transfusi darah (Sari, 2012). Cadangan darah yang tersimpan pada bank darah idealnya adalah $2 \%$ dari jumlah penduduk yang ada. Ketidakseimbangan antara penyediaan darah dan kebutuhan darah semakin meningkat di dunia. Jumlah kebutuhan minimal darah di Indonesia telah mencapai sekitar 5,2 juta kantong per tahun atau $2 \%$ jumlah penduduk, sedangkan penyediaan darah dan komponennya saat ini hanya sebanyak 4,7 juta kantong. Indonesia masih kekurangan jumlah penyediaan darah secara nasional sekitar 500 ribu kantong darah (Kementerian Kesehatan Republik Indonesia, 2019). Proses pengelolaan persediaan darah tersebut memerlukan tingkat keamanan serta kepercayaan yang tinggi untuk tiap langkah prosesnya (Beliën dan Forcé, 2012).

Pentingnya ketersediaan darah di bank darah membutuhkan kesadaran dari masyarakat yang secara sukarela berpartisipasi untuk menyumbahkan darahnya. Ada banyak cara yang dilakukan oleh PMI (Palang Merah Indonesia) yang bekerjasama dengan instansi lain atau relawan dalam meningkatkan kesadaran donor melalui kegiatan-kegiatan pengenalan langsung yang melibatkan berbagai elemen masyarakat baik orangtua, remaja bahkan anak-anak (Annisya, 2017; Mahardika, 2019). Kesadaran masyarakat dalam menyumbangkan darah di Indonesia sudah semakin meningkat tetapi dalam kenyataanya, banyak kandidat yang secara sukarela bersedia donor darah tetapi tidak memenuhi syarat-syarat donor darah yang ditentukan. Seperti hasil penelitian yang dilakukan oleh Pribadi et.al, 2017, partisipasi masyarakat kampus dalam donor darah relatif baik, akan tetapi presentasi keberhasilan presentasi keberhasilan donor darah lebih rendah disebabkan kondisi fisik dan kesehatan yang tidak memenuhi syarat. Dalam penelitiaan Faizah et.al, 2013 didapati kadar hemoglobin dari 129 responden diketahui 34,88\% responden dengan kadar hemoglobin <12 g/dl, sehingga tidak diterima untuk donor darah. Beberapa variabel yang digunakan dalam penelitian Yunus et.al, 2014 dalam penentuan layak donor adalah yaitu golongan darah, jenis kelamin, usia, berat badan, tekanan darah, kadar hemoglobin dan kadar hematocrit (HCT). Masalah-masalah yang mengakibatkan kegagalan melakukan 


\section{Jurnal Analis Medika Biosains (JAMBS)}

Vol.7, No.2, September 2020, pp. 122 - 129

ISSN: 2656-2456 (Online)

ISSN: 2356-4075 (Print)

donor darah meskipun calon pendonor sudah dengan sukarela mendonorkan darah inilah yang menjadi dasar penelitian untuk mengidentifikasi faktor-faktor yang mengakibatkan calon pendonor tidak layak mendonorkan darahnya.

\section{Metode Penelitian}

Data yang digunakan dalam penelitian ini adalah data primer yang diperoleh secara langsung dari responden melalui pemeriksaan kelayakan pendonor darah. Penelitian ini dilakukan di STIKes Santa Elisabeth Medan pada bulan Mei tahun 2019 dengan jumlah responden sebesar 139 orang yang terdiri dari Dosen, Tenaga Kependidikan serta Mahasiswa/i. Pengumpulan data dilakukan melalui observasi yaitu teknik pengumpulan data dengan mengadakan pengamatan terhadap responden penelitian yang secara sukarela bersedia mendonorkan darahnya dan pencatatan secara sistematis terhadap informasi yang diperoleh. Kemudian dilanjut dengan pemeriksaan calon pendonor darah seperti hemoglobin darah, berat badan calon pendonor dan golongan darah diperiksa untuk menentukan responden yang memenuhi syarat melakukan donor darah.

Data pendonor darah yang diperoleh kemudian dikelompokkan berdasarkan atribut-atribut sebagai berikut: nama, jabatan/pangkat, jenis kelamin, usia, berat badan, kondisi hemoglobin dan golongan darah. Pemeriksaan dalam penentuan calon pendonor darah dilakukan dengan bekerjasama dengan PMI (Palang Merah Indonesia) yang menggunakan metode Naive Bayes Classifier untuk menentukan status kelayakan donor Darah yang diklasifikasikan ke dalam kelas "BOLEH DONOR" dan "TIDAK BOLEH DONOR" (Kurniawan, 2014). Prosedur pengambilan darah dilakukan setelah diperoleh responden yang boleh donor yang dilakukan secara aseptik. Hasil pemeriksaan donor darah akan dianalisis dengan SPSS 20 uji Chi square $(p<0.05)$. Prosedur penelitian ini dijelaskan dalam bentuk flow chart yang disajikan pada Gambar 1.

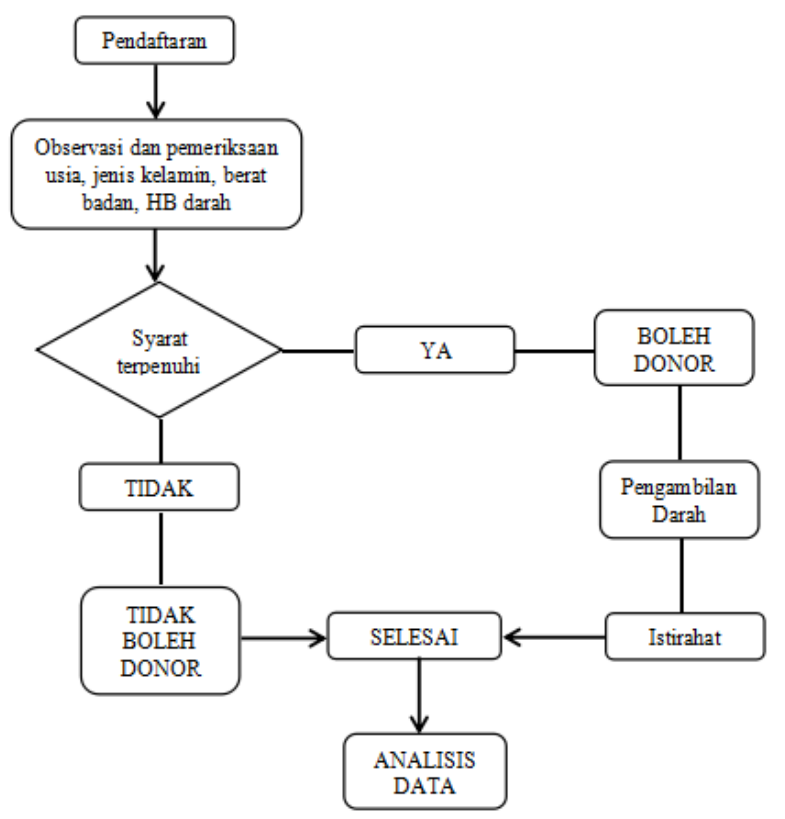

Gambar 1. Flow chart prosedur penelitian 


\section{Hasil Penelitian}

Tabel 1 Karakteristik umum calon pendonor darah di STIKes Santa Elisabeth Medan

\begin{tabular}{|c|c|c|c|c|}
\hline No. & Karakteristik & $\mathrm{n}$ & $\%$ & mean \pm sd \\
\hline \multirow[t]{3}{*}{1.} & Jabatan & & & \\
\hline & Dosen/Tenaga Kependidikan & 8 & 5.76 & \\
\hline & Mahasiswa/i & 131 & 94.24 & \\
\hline \multirow[t]{3}{*}{2.} & Jenis Kelamin & & & \\
\hline & Laki-laki & 12 & 8.63 & \\
\hline & Perempuan & 127 & 91.47 & \\
\hline \multirow[t]{3}{*}{3.} & Umur & & & $20.45 \pm 3.84$ \\
\hline & 16-35 Tahun & 137 & 98.56 & \\
\hline & 36-55 Tahun & 2 & 1.44 & \\
\hline \multirow[t]{3}{*}{4.} & Berat Badan & & & $52.17 \pm 4.89$ \\
\hline & $<50 \mathrm{~kg}$ & 16 & 11.51 & \\
\hline & $\geq 50 \mathrm{~kg}$ & 123 & 88.49 & \\
\hline \multirow[t]{3}{*}{5.} & Status hemoglobin & & & \\
\hline & Normal & 61 & 43.88 & \\
\hline & Tidak Normal & 78 & 56.12 & \\
\hline \multirow[t]{4}{*}{6.} & Status Donor & & & \\
\hline & Boleh Donor & 54 & 38.85 & \\
\hline & Tidak Boleh Donor & 85 & 61.15 & \\
\hline & Total & 139 & 100 & \\
\hline
\end{tabular}

Sebagian besar calon pendonor di STIKes Santa Elisabeth Medan adalah mahasiswa/i (94.24\%) dan terdapat $91.47 \%$ responden dengan jenis kelamin perempuan. Ada $98.56 \%$ responden berada dalam kelompok umur 16-35 tahun dengan rerata umur responden $20.45 \pm 3.84$. Responden sebagian besar memiliki berat badan $\geq 50 \mathrm{~kg}(88.49 \%)$ dengan rerata $52.17 \pm 4.89$ dan status hemoglobin responden normal sebesar $43.88 \%$ sedangkan yang tidak normal ada 56.12\%. Dari hasil pemeriksaan penentuan kelayakan donor, sebagian besar responden tidak memiliki syarat untuk mendonorkan darahnya (61.15\%) dan hanya ada $38.85 \%$ responden yang "Boleh Donor". 
Jurnal Analis Medika Biosains (JAMBS)

Vol.7, No.2, September 2020, pp. 122 - 129

ISSN: 2656-2456 (Online)

ISSN: 2356-4075 (Print)

\section{Tabel 2 Karakteristik umum calon pendonor dengan status "BOLEH DONOR"}

\begin{tabular}{cccc}
\hline No. & Karakteristik & $\mathrm{n}$ & $\%$ \\
\hline 1. & Golongan Darah & & \\
\hline A & 12 & 22.22 \\
\hline B & 9 & 16.66 \\
\hline AB & 3 & 5.56 \\
\hline O & 30 & 55.56 \\
\hline Jenis Kelamin & & \\
\hline Laki-laki & 6 & 11.11 \\
\hline Perempuan & 48 & 88.89 \\
\hline 3. Umur & & \\
\hline & $16-35$ & 53 & 98.89 \\
\hline & $36-55$ & 1 & 1.89 \\
\hline 4. & Berat Badan & 0 & 0 \\
\hline & $\geq 50 \mathrm{~kg}$ & 54 & 100 \\
\hline & $<50 \mathrm{~kg}$ & 54 & 100 \\
\hline & Total &
\end{tabular}

Responden dengan status boleh donor sebagian besar memiliki golongan darah O (55.56\%), jenis kelamin perempuan $(88.89 \%)$ dan berada pada kelompok umur 16-35 tahun (98.89\%). Semua responden yang mendonorkan darahnya memiliki berat badan proporsional yaitu $\geq 50 \mathrm{~kg}$.

Tabel 3 Hubungan jenis kelamin berdasarkan status kelayakan donor darah

\begin{tabular}{|c|c|c|c|c|c|c|}
\hline \multirow[b]{2}{*}{ Item } & \multicolumn{4}{|c|}{ Status Donor } & \multirow{3}{*}{ Total } & \multirow{3}{*}{$\mathrm{p}$-value } \\
\hline & \multicolumn{2}{|c|}{ Boleh Donor } & \multicolumn{2}{|c|}{$\begin{array}{c}\text { Tidak Boleh } \\
\text { Donor }\end{array}$} & & \\
\hline Jenis Kelamin & $\mathrm{n}$ & $\%$ & $\mathrm{n}$ & $\%$ & & \\
\hline Laki-laki & 6 & 50.00 & 6 & 50.00 & 100 & 04 \\
\hline Perempuan & 48 & 37.80 & 79 & 62.20 & 100 & 0.41 \\
\hline
\end{tabular}

Berdasarkan uji statistik menggunakan Chi square test, diperoleh nilai $p=0.41$. Karena nilai $p>0.05$, maka tidak ada hubungan signifikan antara jenis kelamin berdasarkan status kelayakan donor darah pada responden.

Tabel 4 Hubungan jenis kelamin berdasarkan kondisi hemoglobin darah

\begin{tabular}{|c|c|c|c|c|c|c|}
\hline \multirow{2}{*}{ Item } & \multicolumn{4}{|c|}{ Kondisi hemoglobin } & \multirow{3}{*}{ Total } & \multirow{3}{*}{ p-value } \\
\hline & \multicolumn{2}{|c|}{ Normal } & \multicolumn{2}{|c|}{ Tidak Normal } & & \\
\hline Jenis Kelamin & $\mathrm{n}$ & $\%$ & $\mathrm{n}$ & $\%$ & & \\
\hline Laki-laki & 6 & 50.00 & 6 & 50.00 & 100 & 066 \\
\hline Perempuan & 55 & 43.31 & 72 & 56.69 & 100 & 0.66 \\
\hline
\end{tabular}


Hasil ini menunjukkan bahwa 56.69\% perempuan dengan HB tidak normal dan ada 50\% laki-laki dengan HB tidak normal. Sedangkan untuk status HB normal, ada sebesar 50\% laki-laki dan sebesar $43.31 \%$ perempuan. Berdasarkan uji statistik menggunakan Chi square test diperoleh $p=0.66(p>0.05)$, menunjukkan tidak ada hubungan yang signifikan antara jenis kelamin berdasarkan status HB darah.

Tabel 5 . Hubungan berat badan berdasarkan kondisi hemoglobin darah dan status kelayakan donor darah

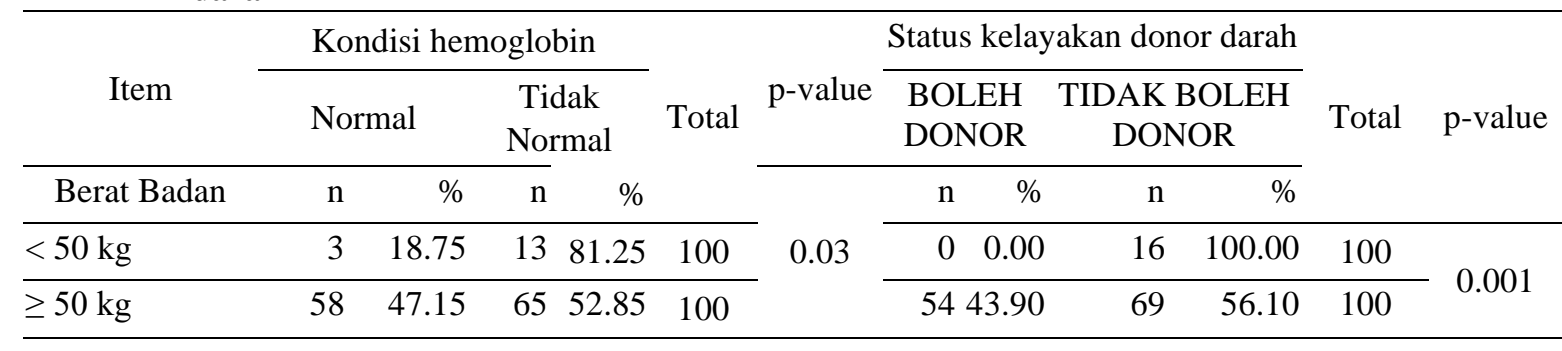

Hasil uji statistik menggunakan Chi Square test diperoleh nilai $p=0.03$ dalam uji hubungan berat badan berdasarkan kondisi hemoglobin dan $p=0.001$ dalam uji hubungan berat badan berdasarkan status kelayakan donor $(p=<0.05)$. Hasil ini menunjukkan bahwa ada hubungan antara berat badan berdasarkan status HB darah dan juga antara berat badan dengan status kelayakan donor darah.

\section{Pembahasan}

Responden terbanyak yang melakukan donor darah adalah mahasiswa/i dimungkinkan karena kondisi kesehatan kaum muda lebih baik serta jumlah mahasiswa di STIKes Elisabeth yang sangat jauh lebih banyak dibandingkan Dosen/Tenaga Kependidikan. Lebih dari 90\% responden adalah perempuan yang menunjukkan bahwa pelajar di STIKes Santa Elisabeth Medan didominasi oleh kaum perempuan. Dalam penelitian ini didapati, kelompok umur 16-35 tahun menjadi calon pendonor darah terbanyak. Pemetaan sesuai kelompok umur dianggap penting karena digunakan sebagai parameter dalam penentuan ukuran tunggal dari tubuh manusia. Umur dibawah 17 tahun ataupun diatas 60 tahun tidak diperbolehkan melakukan donor darah karena dapat berdampak negatif terhadap kesehatan (Palang Merah Indonesia, 2013). Berat badan juga menjadi aspek penting dalam penentuan kelayakan status donor karena pendonor darah menyumbangkan darahnya untuk orang lain dengan jumlah yang bervariasi mulai dari $150 \mathrm{cc}, 250 \mathrm{cc}, 350 \mathrm{cc}$ atau $450 \mathrm{cc}$ sesuai dengan standar yang diperbolehkan berdasarkan berat badan dari pendonor darah. Berat badan minimum yang dapat menjadi pendonor adalah $50 \mathrm{~kg}$ (Handayani \& Haribowo, 2008).

Status hemoglobin tidak normal lebih banyak dibandingkan status hemoglobin normal menunjukkan masalah kesehatan yang kurang baik pada sebagian besar kelompok responden. Hemoglobin berfungsi mengikat dan membawa oksigen dari paru untuk diedarkan ke seluruh tubuh yang dapat dipengaruhi oleh asupan protein, zat besi, asam folat, vitamin C, vitamin A, seng, dan zat lainnya (Nurdini dan Probosari, 2017). Hal ini menunjukkan bahwa status gizi menjadi faktor penting yang mempengaruhi normal tidaknya kadar hemoglobin. Calon pendonor yang memiliki kadar hemoglobin rendah atau memiliki gejala anemia tidak dapat melakukan donor darah (Setyaningsih dkk, 2018; Mohamad Sadikin, 2002). World Health Organization (WHO) mengungkapkan insiden anemia sejak tahun 1993-2005 sebesar 48,8\% dan terdapat 


\section{Jurnal Analis Medika Biosains (JAMBS)}

Vol.7, No.2, September 2020, pp. 122 - 129

ISSN: 2656-2456 (Online)

ISSN: 2356-4075 (Print)

1,62 miliar penduduk dunia yang menderita anemia. Penderita anemia di Indonesia pada tahun 2013 sebesar $21,7 \%$ dan dari keseluruhan penderita, 18,4\% berada pada usia 15-24 tahun. Hal ini sejalan dengan hasil penelitian bahwa usia terbanyak yang tidak memenuhi syarat sebagai pendonor yaitu di rentang usia 16-35 tahun dengan rerata umur $20.45 \pm 3.84$. Penelitian Agustina tahun 2016 terhadap 90 remaja putri di Surakarta juga melaporkan adanya penurunan kadar hemoglobin pada responden.

Banyaknya jumlah responden dengan hemoglobin yang tidak normal menjadi alasan rendahnya responden yang berhasil melakukan donor darah yaitu hanya sebesar 38.85\% dan golongan darah O menjadi yang terbanyak dibandingkan golongan darah lainnya. Mahasiswa/i menjadi salah satu kelompok umur yang rentan mengalami hemoglobin rendah atau gejala anemia karena mahasiswa memiliki jadwal perkuliahan dan berbagai kegiatan dan kadang membuat mahasiswa tidak memperhatikan pola makan dengan baik (jurnal 1). Hal ini mengakibatkan banyak renponden bersedia memberikan sumbangan darah secara sukarela, tetapi syarat-syarat yang diwajibkan untuk mendonorkan darah tidak memenuhi sehingga gagal melakukan donor darah.

Dalam identifikasi faktor-faktor yang mempengaruhi status donor darah responden, didapati jenis kelamin tidak memiliki hubungan yang signifikan dengan status kelayakan donor darah maupun dengan kondisi hemoglobin. Hasil ini tidak sepenuhnya dapat menggambarkan bahwa persentase ketidaklayakan donor darah pada perempuan lebih besar dibandingkan laki-laki karena dalam penelitian ini, responden mayoritas berjenis kelamin perempuan. Berat badan dan kondisi hemoglobin menunjukkan hubungan yang signifikan secara statistik terhadap kondisi status kelayakan donor darah.

\section{Kesimpulan}

Berat badan dan kadar hemoglobin dari responden menjadi aspek terpenting dalam penetuan status kelayakan donor darah, sedangkan jenis kelamin bukan aspek yang berpengaruh signifikan. Penelitian ini merekomendasikan bahwa perbaikan status kesehatan khususnya hemoglobin darah dan berat badan calon pendonor menjadi aspek yang menjanjikan dalam peningkatan keberhasilan donor darah. Penelitian ini dapat digunakan sebagai salah satu bahan untuk menentukan serta mengembangkan atribut-atribut yang dipakai dalam menentukan status kelayakan donor darah.

\section{Daftar Pustaka}

Annisya, A. (2017). "Strategi komunikasi hubungan masyarakat (Humas) palang merah Indonesia (PMI) kota Bima dalam meningkatkan kesadaran masyarakat untuk donor darah." Jurnal Komunikasi dan Kebudayaan 3(1), 1-14.

Beliën, J. and Forcé, H. (2012). "Supply Chain Management of Blood Products: A Literature Review”. European Journal of Operational Research, 217(1), pp. 1-16

Departemen Kesehatan RI. (2001). “Buku Pedoman Pelayanan Transfusi Darah". Departemen Kesehatan RI. Jakarta.

Faizah, N., E. N. Widyaningsih and E. Purwani (2013). "Hubungan antara kadar hemoglobin dan status gizi dengan prestasi belajar remaja di Asrama Putri MTs Surakarta". Universitas Muhammadiyah Surakarta.

Kurniawan, A. (2014). "Penentuan calon pendonor darah menggunakan Algoritma Naive Bayes Classification (Studi Kasus PMI Semarang)". Universitas Dian Nuswantoro, Semarang. 


\section{Jurnal Analis Medika Biosains (JAMBS)}

Vol.7, No.2, September 2020, pp. 122 - 129

ISSN: 2656-2456 (Online)

ISSN: 2356-4075 (Print)

Lestariyani, N. K. and S. Herawati (2017). "Perbedaan jumlah trombosit konsentrat trombosit pada penyimpanan hari i, iii, v di Unit Donor Darah PMI provinsi Bali/RSUP Sanglah Denpasar". E-Jurnal Medika Udayana 6(3).

Mahardhika, G. P. (2019). "Gim proses donor darah sebagai alat promosi donor darah". JMAI (Jurnal Multimedia \& Artificial Intelligence) 3(1): 9-16.

Munandar, H. (2008). Mengenal PMI dan BaSARnas, Dua Garda Terdepan Menghadapi Bencana: Misi, Peranan, serta Arti Penting PMI dan BaSARnas bagi masyarakat luas, Esensi.

Nurdini, D. A. and E. Probosari (2017). "Tingkat kecukupan zat gizi dan kadar hemoglobin pada atlet sepakbola". Diponegoro University.

Pribadi, T., \& Yanti, E. V. (2018). "Peningkatan partisipasi masyarakat dalam kegiatan donor darah di Palangka Raya". Jurnal Pengabdian Al-Ikhlas Universitas Islam Kalimantan Muhammad Arsyad Al Banjary, 3(1).

Sari, L. P. (2012). "Faktor-faktor yang memengaruhi pendonor darah sukarela pada masyarakat non-pribumi dan pribumi di Unit Transfusi Darah Palang Merah Indonesia Kota Medan".

Setyaningsih, R. I., D. R. Pangestuti and M. Z. Rahfiludin (2018). "Hubungan asupan protein, zat besi, vitamin c, fitat, dan tanin terhadap kadar hemoglobin calon pendonor darah laki-laki (Studi di Unit Donor Darah PMI Kota Semarang)". Jurnal Kesehatan Masyarakat (e-Journal) 6(4): 238-246.

Sugesty, Y., S. Sulastri and R. Proborini (2019). "Pengaruh pemberian informasi melalui brosur dan ceramah terhadap minat donor darah pemula di sekolah". Jurnal Psikologi Malahayati 1(1).

Wardati, W. and A. J. Hadi (2019). "Faktor yang memengaruhi perilaku donor darah di unit transfusi darah rs dr. fauziah bireuen". MPPKI (Media Publikasi Promosi Kesehatan Indonesia): The Indonesian Journal of Health Promotion 2(3): 181-185.

Wardati, W. and A. J. Hadi (2019). "Faktor yANG mEMENGARUHI pERILAKU dONOR dARAH di Unit Transfusi Darah Rs Dr. Fauziah Bireuen." MPPKI (Media Publikasi Promosi Kesehatan Indonesia): The Indonesian Journal of Health Promotion 2(3): 181-185.

Yunus, M., H. S. Dachlan and P. B. Santoso (2014). "SPK pemilihan calon pendonor darah potensial dengan Algoritma C4. 5 dan Fuzzy Tahani." Jurnal EECCIS 8(1): 47-54. 